\title{
Physicochemical Assessment of Water Quality in Selected Borehole in Anyigba Town, Kogi State, Nigeria
}

\author{
"SALE, JF; YAHAYA, A; EJIM, CC; OKPE, IW \\ Department of Pure and Industrial Chemistry, Kogi State University, Anyigba \\ *Corresponding Author Email: salejf4love@yahoo.com
}

\begin{abstract}
Borehole is an important source of water on which many people in Anyigba metropolis depend for their livelihood. The people of Anyigba in Kogi East of Nigeria depends on this source of water for domestic purpose and other uses hence the need to investigate the quality of the water to ascertain it suitability for domestic and other uses. The physicochemical properties of the water were analyzed using different standard analytical techniques: UVspectrophotometer was used to analyze Nitrate, Sulphate and Ammonia in the water samples. Also, Flame photometer was used to analyze Calcium, Potassium and Sodium in the water samples. the results of the physicochemical analyzed showed the following ranges: $\mathrm{pH} 6.5-7.6 \mathrm{mg} / \mathrm{L}$, Temperature $26-28^{\circ} \mathrm{C}$, Conductivity $10-20 \mathrm{us} / \mathrm{cm}$, Dissolved oxygen 0.49 $9.3 \mathrm{mg} / \mathrm{l}$, Total alkalinity $10-20 \mathrm{mg} / \mathrm{l}$, Total hardness $18-40 \mathrm{mg} / 1$, chloride $28.4-71 \mathrm{mg} / \mathrm{l}$, Acidity $210 \mathrm{mg} / 1$, Sodium 33.5 $38.4 \mathrm{mg} / \mathrm{l}$, Potassium 9.90-10.70mg/l, Calcium 92.5-167.8mg/l, Nitrate 26-35mg/l, Ammonia 79-107mg/l and Sulphate $42.5-78 \mathrm{mg} / \mathrm{L}$. Some of the parameters were observed to be within the permissible limit stipulated by the World Health Organization, there is still need to protect the underground water bodies against any in flush of pollutants.
\end{abstract}

\section{DOI: https://dx.doi.org/10.4314/jasem.v23i4.21}

Copyright: Copyright (C) 2019 Sale et al. This is an open access article distributed under the Creative Commons Attribution License (CCL), which permits unrestricted use, distribution, and reproduction in any medium, provided the original work is properly cited.

Dates: Received: 30 February 2019; Revised: 24 March 2019; Accepted 15 April 2019

Keywords: Borehole, Pollution, physicochemical, Quality

Water is a transparent and colourless chemical substance that is the main constituent of earth's streams, lakes and oceans. It's also the fluids of most living organisms. Its chemical formula is $\mathrm{H}_{2} \mathrm{O}$, meaning that each of its molecules contain one oxygen and two hydrogen atoms that are connected by covalent bonds. Water covers $71 \%$ of the earth surface its vital for all known forms of life on earth, 96.5\% of the planets crust water is found in seas and oceans, $1.7 \%$ in ground water and $1.7 \%$ in glaciers, a very small fraction in other large water bodies, $0.001 \%$ in the air as vapours, only $2.5 \%$ of this water is freshwater, only $98.8 \%$ of that water is in ice. Safe drinking water is essential to humans and other life forms even though it provides no calories or organic nutrients. All living organism need water for survival and growth, therefore it is necessary that the quality of drinking water should be checked regularly at time intervals, because due to use of contaminated drinking water, human population suffers from varied of water borne diseases (Ranjankar, 2013). The availability of good quality water is an indispensable for preventing diseases and improving quality of life. Natural water contains different types of impurities which are introduced into the aquatic system by different ways such as weathering of rocks, leaching of soils, and dissolution of aerosol particles from the atmosphere and from human activities, including mining, processing and the use of metal based materials. The increased use of metal based fertilizers in agricultural revolution of the government could result in continued rise in concentration of metal pollutions in fresh water reservoir due to the water run-off. Also factual pollution of drinking water causes water borne disease which has lead to the death of millions of people (Obi and Okocha, 2007). High level of pollutants mainly organic matter in water causes an increase in biological oxygen demand, chemical oxygen demand, total dissolved solids and total suspended solids. They make water unsuitable for drinking, irrigation or any other use (Karvitha and Elangovan, 2010). The quality of ground water depends on various chemical constituents and their concentration, which are mostly derived from geological data of the particular region. Industrial waste and the municipal solid waste have emerged as one of the leading cause of pollution of surface and ground water. Lack of safe drinking water and adequate sanitation measures lead to number of diseases such as cholera, dysentery, salmonellosis and typhoid, (Obi and Okocha, 2007). In less industrialized areas, pollution from human settlements lacking appropriate sanitary infrastructure, partially treated or untreated wastewater, leachates from refuse dumps and from land use activities such as agriculture are the 
major pollution sources of the ground water. Microbiological and the physical water quality indicators are therefore the major parameters to be monitored in the rivers, dams or boreholes of catchments (Sale et al., 2001). Meteorological events and pollution are a few of the external factors which affects physicochemical parameters such as $\mathrm{pH}$, temperature, turbidity etc. of the water. They have a major influence on the biochemical reactions that occur within the water. Sudden changes of these parameters may be indicative of changing conditions in the water. Internal factors on the other hand, include events, which occur between and within bacterial and plankton population in the water body (Niranjan, 2011).

Polluted ground water is less visible, but more difficult to clean up, than pollution in rivers and lakes ground water pollution most often results from improper disposal of waste on land. Major sources include industrial and household chemicals and garbage landfills, industrial waste lagoons, tailings and process waste water from mines, oil field brine pits, leaking underground oil storage tanks and pipelines, sewage sludge and septic systems. Polluted ground water is mapped by sampling soils and ground water near suspected or known sources of pollution, to determine the extent of pollution and to aid in design of ground water remediation systems. Preventing groundwater pollution near potential sources such as landfills requires lining the bottom of a landfill with watertight materials, collecting any leachate with drains, and keeping rainwater off any potential contaminants, along with regular contaminants, along with regular monitoring of nearby groundwater to verify that contaminants have not leaked into the ground water. Ground water pollution, from pollutants released to the ground that work their way down into groundwater, can create a contaminant plume within an aquifer. Pollution can occur from landfills, naturally occurring arsenic on-site sanitation systems or other point sources, such as petrol stations or leaking sewers (Obi and Okocha, 2007). Movement of water and dispersion within the aquifer spread the pollutant over a wider area, it is advancing boundary often called a plume edge, which can then intersect with ground water well or daylight into ground water well or daylight into surface water such as seeps and springs, making the water supplies unsafe for humans and wild life different mechanism have influence on the transport of pollutants, e.g. diffusion, adsorption, precipitation, decay, in the ground water. The interaction of ground water contamination with surface water is analyzed by use of hydrology transport models. The danger of pollution of municipal is minimized by locating wells in the areas deep ground water and impermeable soils, and careful testing and monitoring of the aquifer and nearby potential pollution sources (Balbus and Embrey, 2002). The purpose of this study was to determine the physicochemical quality of Borehole water sources used by some selected rural communities in Anyigba Local Government Area of Kogi state

The Study Area: This research was carried out in some selected areas in Anyigba metropolis which is a town in Dekina local government area of Kogi State with the headquarter in Dekina town. The study area is on the A233 highway in the north of the area at $7^{0} 41^{\prime} 4^{\prime \prime} \mathrm{N}$ and $7001^{\prime} 20^{\prime \prime} \mathrm{E}$. The north easterly line of equal latitude and longitude passes through the south east of the local government area. It has an area of $2.461 \mathrm{~km}^{2}$ and a population of 260,312 at the 2006 census.

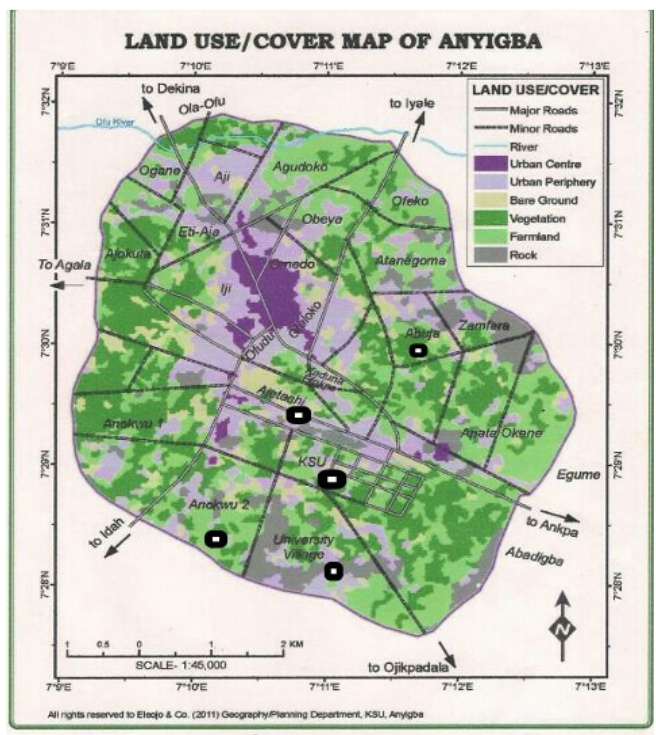

Fig 1: Map of Anyigba in Dekina local government showing the study

\section{MATERIALS AND METHODS}

Sample Locations: Samples were collected from five different locations which are Ajetachi, Anokwu 2, KSU (University campus), University village and Abuja area in Anyigba metropolis.

Sample Collection: The rubber containers used for collecting samples at various points were washed thoroughly and rinsed with distilled water and then with the samples to be collected. The containers were filled completely with water and the lid served tightly.

Sample Treatment and Storage: The sample containers were clearly labeled for easy identification of the various points of collection. They were carried in a clean leather bag to the laboratory. The water samples 
were refrigerated at $4^{\circ} \mathrm{c}$ in a thermostated refrigerator before analysis. The temperature was determined using the mercury in glass thermometer. Electrical conductivity was measured using the Hanna electrical conductivity meter. Dissolved oxygen was done using dissolved oxygen meter. Total alkalinity by potentiometric titration, $\mathrm{pH}$ was measured using $\mathrm{pH}$ Meter. The acidity was determined by titrating the sample with a standard base.

Determination of Ammonia, Nitrate, Sulphate, by UV/Visble Spectrophotometry: Thermo Evolution 600 UV/Visible Spectrophotometer computer based automated model was used for the analysis of the above parameters in all the samples. The instrument was switched on and allowed to initialize fully for a warm up time of about 2 hours. The quant mode single wavelength was selected followed by appropriated wavelength of the analyte of interest (wavelengths for ammonia $=410 \mathrm{~nm}$; nitrate $=543 \mathrm{~nm}$; nitrite $=543 \mathrm{~nm}$; sulphate $=420 \mathrm{~nm}$ ) Standard curve for each parameter was a calibration performed at 0.999 , correlation coefficient under ideal condition internally in the laboratory and stored in the system memory subject to review every three months or when it fails reliability test performed before each analysis. Samples were then prepared according to standard methods for analysis for water and wastewater (APHA, 1998). Duplicate and quality control samples were analysed in every batch of 10 samples to ensure that the results were within controls.

Determination of Chloride by Argentometric Method: $100 \mathrm{ml}$ of sample was measured into $250 \mathrm{~mL}$ conical flask. Samples whose $\mathrm{pH}$ were not in the range of 7 to 10 were adjusted to this range prior to titration using $\mathrm{pH}$ meter with a non chloride type electrode. $1 \mathrm{ml}$ of $\mathrm{K}_{2} \mathrm{CrO}_{4}$ was added to the sample as indicator and then titrated with standard $0.0141 \mathrm{AgNO}_{3}$ as titrant to a pinkish yellow end point. The same procedure was followed for all the samples. A blank titration was done using distilled water by adopting the same procedure above (APHA, 1998).

Calculation: (A-B) x M x 34500/mL of sample used

Where $\mathrm{A}=$ volume of titrant used for the sample; $\mathrm{B}=$ volume of titrant used for the blank; $\mathrm{M}=$ molarity of the titrant used

Determination of Sodium, Potassium and Calcium by Flame Emission Spectrophotometry: Sodium and potassium in all the samples were analysed using Shewood Scientific Limited Flame Photometer Model 410. The fuel supply of the instrument at the source was turned on and the appropriate filter selector was set to the required position. The nebulizer inlet tube was inserted into a beaker containing $100 \mathrm{~mL}$ of diluent and allowed 30 minutes for the operating temperature to stabilize. This was to ensure a stable burner temperature when solutions were aspirated. During the warm up period a set of calibration solutions of $0.0,2.0,4.0,6.0,8.0$ and $10.0 \mathrm{ppm}$ were prepared for sodium and potassium. While aspirating the diluent, the blank control on the instrument was adjusted so that the display reads 0.0 . The highest concentration of standard (in this case) $10 \mathrm{ppm}$ was aspirated while 20 seconds allowance was given for a stable reading before the coarse and fine controls were adjusted for instrument to read 100. The standard solution was removed and waited for 10 seconds, and then a blank solution of diluent was aspirated for 20 seconds before adjusting the blank control for 0.0 reading. The blank was removed and waited for another 10 seconds before the highest standard was reaspirated again. This was repeated until the blank reading was 0.0 (within \pm 0.2 ) and the calibration reading was within $\pm 1 \%$. Without touching the fine and coarse controls each of the remaining standards were aspirated for 20 seconds (starting with the lowest concentration to avoid carry over) again allowing 10 seconds between measurements. The value of each standard from the instrument response was noted and the results plotted against concentration on linear excel graph. Each of the samples was then aspirated for 20 seconds and the concentration of the unknown samples estimated from the caliberation curve (APHA, 1998).

Determination of Total Hardness by Titrimetry:

$50 \mathrm{~mL}$ of water sample was transferred into $250 \mathrm{~mL}$

Erlenmeyer flask by graduated cylinder. The $\mathrm{pH}$ was adjusted to about 10 by adding a sufficient volume of buffer. 2 drops of calgamite indicator was added and titrated slowly with $0.01 \mathrm{M}$ EDTA solution with continuous stirring until colour changed from red wine to sky blue. This procedure was repeated for all the samples.

Calculation:

Total hardness as $\mathrm{CaCO}_{3} \mathrm{mg} / \mathrm{L}=(\mathrm{A}-\mathrm{B}) \times \mathrm{D} \times 1000 / \mathrm{mL}$ sample

Where; $\mathrm{A}=\mathrm{mL}$ of titrant used for the sample; $\mathrm{B}=\mathrm{mL}$ of titrant used for the blank; $\mathrm{D}=\mathrm{mgCaCO}_{3}$ equivalent to $1.00 \mathrm{~mL}$ EDTA titrant.

Magnesium hardness, calcium ion and magnesium ion in all the samples were estimated by calculation.

\section{RESULTS AND DISCUSSION}

Analysis carried out on five water samples and the results obtained are as presented in table 1 . 
Table 1: Results of the physicochemical analysis

\begin{tabular}{|c|c|c|c|c|c|c|c|c|c|c|c|c|c|c|}
\hline SAMPLES & $\begin{array}{l}\mathrm{Na}^{+} \\
\text {(ppm) }\end{array}$ & $\begin{array}{l}\mathrm{K}^{+} \\
\text {(ppm) }\end{array}$ & $\begin{array}{l}\mathrm{Ca}^{2+} \\
\text { (ppm) }\end{array}$ & $\mathrm{pH}$ & $\begin{array}{l}\text { Tem } \\
\text { (K) }\end{array}$ & $\begin{array}{l}\text { Coduc } \\
\text { (us/cm) }\end{array}$ & $\begin{array}{l}\text { DO } \\
\text { (ppm) }\end{array}$ & $\begin{array}{l}\text { TA } \\
\text { (ppm) }\end{array}$ & $\begin{array}{l}\text { TH } \\
\text { (ppm) }\end{array}$ & $\begin{array}{l}\text { Chloride } \\
\text { (ppm) }\end{array}$ & $\begin{array}{l}\text { Acidity } \\
\text { (ppm) }\end{array}$ & $\begin{array}{l}\mathrm{NO}_{3}^{-} \\
\text {(ppm) }\end{array}$ & $\begin{array}{l}\mathrm{SO}_{4}{ }^{2} \\
\text { (ppm) }\end{array}$ & $\begin{array}{l}\mathrm{NH}_{3} \\
\text { (ppm) }\end{array}$ \\
\hline $\mathrm{KS}$ & 36.4 & 10.3 & 92.5 & 7.5 & 26 & $1 \times 10^{1}$ & 5.1 & 20 & 18 & 49.7 & _- & 34 & 61 & 98 \\
\hline $\mathrm{AJ}$ & 36.9 & 10.2 & 128.2 & 7.0 & 26 & $1 \times 10^{1}$ & 1.5 & 10 & 26 & 35.5 & - & 35 & 78 & 79 \\
\hline UV & 33.5 & 9.90 & 117.1 & 7.5 & 26 & $1 \times 10^{1}$ & 0.49 & 15 & 40 & 63.9 & & 33.5 & 64 & 107 \\
\hline AK & 33.9 & 10.30 & 167.8 & 6.5 & 28 & $1 \times 10^{1}$ & 1.0 & 15 & 34 & 71 & $\overline{2} 10$ & 26 & 42.5 & 98 \\
\hline$A B$ & 38.4 & 10.70 & 143.2 & 7.6 & 26 & $2 \times 10^{1}$ & 9.3 & 15 & 20 & 28.4 & - & 28 & 55 & 106 \\
\hline WHO & 20 & NL & 200 & $6-8.5$ & _ & $1.2 \times 10^{3}$ & 18 & 100 & 26 & 250 & 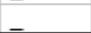 & 50 & 500 & 10 \\
\hline
\end{tabular}

The results of the analysis of the physicochemical parameters in the bore-hole water samples were provided in Table 1 above; The $\mathrm{pH}$ values for the five sampled water falls within 6.5-7.6 and was found to be within the limit stipulated by the WHO standard for ground water(6.0 to 8.5). This $\mathrm{pH}$ values obtained shows that the water samples are safe for human consumption. The five samples measured showed alkalinity below WHO standard which is $100 \mathrm{mg} / \mathrm{l}$, the sample values fall within the range of 20.0 to 63.5 $\mathrm{mg} / \mathrm{l}$. The concentrations of chloride for all sampled sites were below WHO standard $250 \mathrm{mg} / \mathrm{l}$, the values obtained ranges from $28.4 \mathrm{mg} / \mathrm{l}$ to $71 \mathrm{mg} / \mathrm{l}$.

For total hardness, the values obtained some were within the range and some were above the WHO standard of $26.0 \mathrm{mg} / \mathrm{l}$. The concentrations of nitrate were below the WHO permissible limit in drinking water of $50 \mathrm{mg} / \mathrm{l}$, nitrate in the present work ranges from $26.0 \mathrm{mg} / \mathrm{l}$ to $35 \mathrm{mg} / \mathrm{l}$. For total dissolved oxygen, the values obtained are below the WHO standard of 18 $\mathrm{mg} / \mathrm{l}$, the values range from $0.49 \mathrm{mg} / \mathrm{l}$ to $9.3 \mathrm{mg} / \mathrm{l}$. The results obtained shows low level of conductivity when compared with the WHO standard of $1200 \mathrm{us} / \mathrm{cm}$, the values obtained range from $1 \times 10^{1} \mathrm{us} / \mathrm{cm}$ to $2 \times 10^{1}$ us $/ \mathrm{cm}$. The values obtained shows low level of sulphate when compared to the WHO standard of 500 $\mathrm{mg} / \mathrm{l}$, the values ranges from $42.5 \mathrm{mg} / \mathrm{l}$ to $78 \mathrm{mg} / \mathrm{l}$. All the water samples analyzed have high levels of $\mathrm{NH}_{3}$ when compared to WHO standard $10 \mathrm{mg} / \mathrm{l}$, the values ranges from $79 \mathrm{mg} / \mathrm{l}$ to $107 \mathrm{mg} / \mathrm{l}$. This is due to the presence of inorganic contaminants in the water samples. One of the water samples is very acidic showing value of $210 \mathrm{mg} / \mathrm{l}$ and $\mathrm{pH}$ of 6.5 . All the samples shows high level of $\mathrm{Na}^{+}$when compared with the WHO standard of $20 \mathrm{mg} / \mathrm{l}$, the values obtained ranges from $33.5 \mathrm{mg} / \mathrm{l}$ to $38.4 \mathrm{mg} / \mathrm{l}$. The concentrations of $\mathrm{Ca}^{2+}$ in the water samples are below the WHO standard of $200 \mathrm{mg} / \mathrm{l}$, the values ranges from $92.5 \mathrm{mg} / \mathrm{l}$ to $167.8 \mathrm{mg} / \mathrm{l}$.

Conclusion: The results obtained from the physicochemical analysis indicated that $\mathrm{pH}$, total hardness was within the permissible limit of WHO. Total alkalinity, chloride $\left(\mathrm{Cl}^{-}\right)$, nitrate, dissolved oxygen, conductivity, sulphate and calcium were below the WHO standard. Also elevated concentration of $\mathrm{NH}_{3}$ was due to the presence of inorganic contaminants in the water samples. Consequently, further work should be carried out to determine the concentration of parameter periodically and the Federal Government of Nigeria should empower environmental Agencies to always check the level of pollutants in underground water bodies.

\section{REFERENCES}

Ademoroti, C.M.A. (1996). Environmental chemistry and Toxicology. Foludex press ltd; Ibadan, pp79-208.

APHA (1998). Standard methods for examination of water and waste water, $18^{\text {th }}$ edition, American public Health Association Washington DC, USA.

Balbus J.M, Embrey M.A (2002). Risk factors for water borne enteric infections.

Beuro of Indian Standards for Drinking water 2012 (BIS2012).

Dwaf (1996). Physicochemical and microbiological quality of water. South Africa Quality guidelines Vol. 1. (pp 1820).

Kavitha R; Elangovan K. (2010). Review Article on Groundwater Quality characteristics at Erode district, (India), of I.J.E.S., 1(2).

Mathew J.D (1984). Physicochemical analysis of rural water sources, evidence for the role of copper in the injury process of coliform bacteria in drinking water. Appl. Environ. Microbial. 48 (8). 289-293.

Manual on Water and Waste-water Analysis (1988). National Environment Engineering Research Institute, Nagpur.

Niranjan K. (2011). Ground Water Quality Assessment of Wailpalli Nalgonda, Indian J. Environ. Sci. 15(1). 6976.

Obi C.N, and Okocah C.O. (2007). Microbial and Physicochemical Analysis of Selected Bore Hole Waters.

Rajankar P. (2013). Assessment of Ground Water Quality using water quality index (WQI) in Wardha Maharashtra. J. Environ. Sci. Sustain. 1(2), 49-54.

Sale M.A. Emmanuel E. Joseph J. Wilson B.L. (2001). Chemical Evaluation of Bottled Drinking Water from Egypt. J. Food Compo. Analysis 127-152. 